\title{
The Three Sources of Legitimacy for European Fiscal Policy
}

\author{
Stefan Collignon \\ London School of Economics and Harvard University \\ www.stefancollignon.de
}

\author{
A paper presented at the workshop: \\ Which Social and Tax Policy for which European Union? \\ Stockholm, 10-11 June, 2005 \\ CIDEL-ARENA-SCORE
}

\begin{abstract}
Fiscal policy has remained under the authority of national governments in Euroland, while monetary policy is unified in the hands of the ECB. This arrangement does not produce optimal results. This paper looks at the normative foundations of fiscal policy in the EU, by mapping the allocative function, stabilisation and redistribution policies into three models of legitimacy, the problem-solving EU, the communitarian model and the European Republic.
\end{abstract}




\title{
The Three Sources of Legitimacy for European Fiscal Policy
}

\author{
Stefan Collignon $^{1}$
}

Europe's economic governance is incomplete. While monetary policy is under control of the European Central Bank (ECB) and committed to price stability, nobody is in charge of stabilisation policy in the broader sense, which includes internal and external equilibrium, and most notably unemployment. The interaction between monetary, fiscal and income policies is crucial for achieving simultaneously stable prices, balanced growth and high employment. Yet, in Euroland the outcome of this "policy mix" is not the result of coherent policy options. Budget decisions are decentralised and taken in the context of national constituencies. The Stability and Growth Pact (SGP) provides a set of rules stipulating how each national authority ought to behave, but the aggregate European level, which matters for monetary policy, is only the sum of twelve random processes. This means, that fiscal policy cannot be used as a policy tool, because it cannot be flexibly adapted to changing circumstances. Given that wage bargaining has remained compatible with the stability objectives of the ECB, the indeterminacy of European fiscal policy must be a key for the euro's disappointing economic performance. There are good reasons to believe that the policy mix in Euroland is suboptimal (Collignon, 2004). However, this is not the topic of this paper. The real problem is not so much "bad policy" or insufficient application of collective decisions. It is institutional. While economists have intensely debated the role of fiscal policy and the interaction with monetary policy, they usually assume both policy domains under the control of unified and coherent actors and analyse how these actors optimise some objective function, under given constraints. But in Europe there is no unified fiscal actor, because each member state has the authority for its budget policy. Politically, this is understandable. "no taxation without representation” is a founding value of democracies. We need to address, therefore, a more fundamental question: what are the sources of legitimacy for an integrated fiscal policy? Part of the difficulty of improving the EU's economic performance is the lack of consensus and the ideological incompatibilities underlying the interpretation of budget policies and ultimately of the state in Europe's economy. I will focus on the

\footnotetext{
${ }^{1}$ London School of Economics and Harvard University
} 
normative foundations of fiscal policy in Euroland and analyse, how three wellestablished normative models of European integration contribute to very different and often incompatible visions of the role of fiscal policy in monetary union. First, I will recall the three classical functions of public finance in the European context and then I will map them into the normative framework of European integration.

\section{The Classical Functions of Public Finance.}

Does fiscal policy matter and for what? By fiscal policy we mean decisions relating to the level of expenditure, taxes and their balances and the evolution of these aggregates over time. To understand their impact it is useful to refer to the classical distinction of the three functions of public finance: allocation, stabilisation and re-distribution.

\section{The allocation function}

By allocating resources to different uses in accordance with consumers' preference rankings their welfare is maximised. Notice, that welfare and efficiency are implicitly defined by the utility function (the index of individual and collective preferences over a range of applications). The statement about efficiency does not claim any particular distribution of outcomes, which depend on the initial distribution of resources, but simply that it is not possible to achieve higher output with given resources. In Europe, the allocation issue has a nearly constitutional status, because European integration is based on market building by removing obstacles to trade. By integrating fragmented markets, allocative static as well as dynamic gains in income and welfare can be obtained (Altomonte and Nava, 2005). Economists usually assume preferences to be exogenously given, and they silently pass over the question how the utility index is established. With respect to private goods, this is rather unproblematic. Because a consumer, who is not willing to pay, can be excluded from market transactions, one can leave it to markets to ensure that individuals reveal their preferences correctly by spending decision. Hence, markets are the mechanism whereby private goods are allocated efficiently when marginal costs equal marginal utility. GDP is then an appropriate indicator of welfare. 
This is less obvious for public goods. Here, the supply (allocation of resources) or consumption of goods (allocation to preferences) cannot be confined to individuals who are willing to pay. There would be no problem, if all consumers had the same preference of consuming the collective good, because decisions by unanimity resemble individual choice (the representative agent model). ${ }^{2}$ However, difficulties arise when there are heterogeneous preferences and one person's supply or consumption of a good affects the utility of another individual. This externality breaks the link between resource allocation and the efficiency criteria of welfare. The social marginal cost and benefits of supplying a public good must include the cost and benefits of the externality. In order to re-establish the link, externalities need to be "internalised", which means a mechanism is needed, whereby all those, whose utility function is affected by the allocation of resources, must contribute to the definition of the collective preference.

To avoid misunderstandings, I need to emphasise that this internalisation problem cannot be solved by decentralisation or subsidiarity. The classical theory of fiscal federalism (Oates, 1972) states that if public goods can be supplied by different levels of jurisdiction, then the "highest" or most centralised level should provide the goods that service the whole population. But those goods, which affect only parts or smaller groups of the population, should be supplied by an authority responsive to the specific preferences of that group. This is an obvious claim. There is no need to provide, e.g. snowploughs to sub-Saharan Africa. But in recent years, the argument has been taken much further. It is now claimed (see e.g. Alesina and Wacziarg, 1999) that local governments know best, and therefore efficient government (or even optimal sizes of countries) are determined by preference homogeneity (or to be precise by the trade-off between preference homogeneity and economies of scale or other exogenous externalities). This argument is too narrow, because it ignores the externalities that the realisation of one person's preference may have on another. For example if the regulation of my condominium prevents me from having wild parties, I will be frustrated. But if we decentralise with the argument that "I know best what is good for me”, the desire of my neighbour to have peace and quiet may be disturbed. We

\footnotetext{
${ }^{2}$ Knut Wicksell (1896) was the first to recognize that the rule of unanimity for reaching collective decisions provides the institutional analogue to two-person trade in strictly private or partitionable goods. The theme was later rediscovered by Buchanan (see 1975).
} 
therefore need a mechanism, which permits the agreeable regulation of our common good.

Traditionally, this has been the role of government, which, according to David Hume (1978:539), is "one of the finest and most subtle inventions imaginable". Governments internalise externalities by passing laws and regulations and by imposing taxes in order to provide public goods. They optimise welfare when appropriate tax rates bring private marginal costs into line with social costs. For Adam Smith, taxing individuals was justified, if it served protecting society from violence and invasion (1976:689), from injustice and oppression (1976:708) and erecting and maintaining institutions, which "though they may be in the highest degree advantageous to a great society, are, however, of such a nature that the profit could never repay the expense to any individual or small number of individuals and which, it, therefore, cannot be expected that any individual or small number of individuals should erect or maintain" (Smith 1976:723). This is the classical argument for burden sharing in the presence of externalities. However, there is no guarantee that resources will be allocated optimally to the production of public goods, even if that would improve welfare. Voluntary cooperation amongst potential beneficiaries alone is not sufficient. Well before Adam Smith, David Hume had already seen that collective action problems and time inconsistent preferences were likely to prevent the optimal supply of collective goods and he concluded that a "government" or "political society" was needed:

"There is no quality in human nature, which causes more fatal errors in our conduct, than that which leads us to prefer whatever is present to the distant and remote, and makes us desire objects more according to their situation than their intrinsic value. Two neighbours may agree to drain a meadow, which they possess in common; because 'tis easy for them to know each others mind; and each must perceive, that the immediate consequence of his failing in his part, is, the abandoning of the whole project. But 'tis very difficult, and indeed impossible that a thousand persons shou'd agree in any such action; it being difficult for them to concert so complicated a design, and still more difficult to execute it; while each seeks a pretext to free himself of the trouble and expense, and would lay the whole burden on others. Political society easily remedies both these inconveniences" (Hume, 1978:538).

Thus, externalities and the need to deal with them were already recognised by the early classics as part of the system of natural liberties (Musgrave, 1999). The argument for a European political union can therefore be traced back as far as to 
David Hume and Scottish enlightenment. Until today, collective action problems and time inconsistency are powerful arguments for government regulation of the economy. However, these problems do not necessarily require big government. Regulating private activities by social and legal norms may be enough to internalise externalities. Thus, government can be small and still a strong regulator. However, collective action problems arise, when individuals have incentives to behave contrary to the established norms. The public interest will then need to be safeguarded by a single, unified agent, i.e. by government.

This poses two questions. First, what are the criteria for deciding, which externalities can be regulated by norms and which ones by delegation to the government? It can be shown that the rule-based regulative framework will work, when the transactions between individuals are characterised by strategic complementarities. This describes the situation when the marginal utility of one agent increases, if all agents other than himself, implement a certain policy rule (Cooper and John, 1988). For example following traffic rules is such behaviour, as my safety increases if everyone else conforms. Knowing this, I will also conform. It may still be necessary, to use surveillance agents to prevent imperfect information from producing sub-optimal equilibria, but in essence the arrangement is self-sustaining. However, this model breaks down in the case of strategic substitutabilities. The marginal utility of one individual would then be reduced by her following the norm everyone else is following. Individual behaviour, therefore, tends to do the opposite of what collective interest requires and public goods will not be provided optimally. For example, my marginal (net) utility falls if I have to pay taxes for a collective project. But if I could avoid paying and still benefit from it, while everyone else paid up, this free-riding would increase the tax burden for everyone else, but lower mine. As everyone else would like to do the same, resources are nor efficiently allocated to the project. A government is therefore needed, as Hume understood, to ensure the optimal allocation of resources to public goods. I have argued (Collignon, 2003, 2004a) that fiscal policy, and especially the definition of the aggregate fiscal policy stance in Euroland, is dominated by strategic substitutabilities.

A second question is, how large the public sector should be. Since Adam Smith, (neo)liberals have aimed for small public sectors, but market failure and increasing 
externalities may push the argument in the opposite direction. As I will discuss below, the preferences for small or large public sectors are, in democracies, the result of intense and drawn out policy debates taking place between parties and among citizens within the given constitutional framework. Therefore, constitutions and constituencies will pre-structure policy outcomes.

Figure 1 indicates the variations of total public expenditure for some selected countries. The size and variations of the public sector are significantly higher in Europe than in the United States. Scandinavia and France prefer a public share well above 50 percent of GDP, Germany and Europe as a whole between 45 and 50 percent; only Ireland has collective preferences that are comparable to the US.

Figure 1. Government expenditure as share of GDP

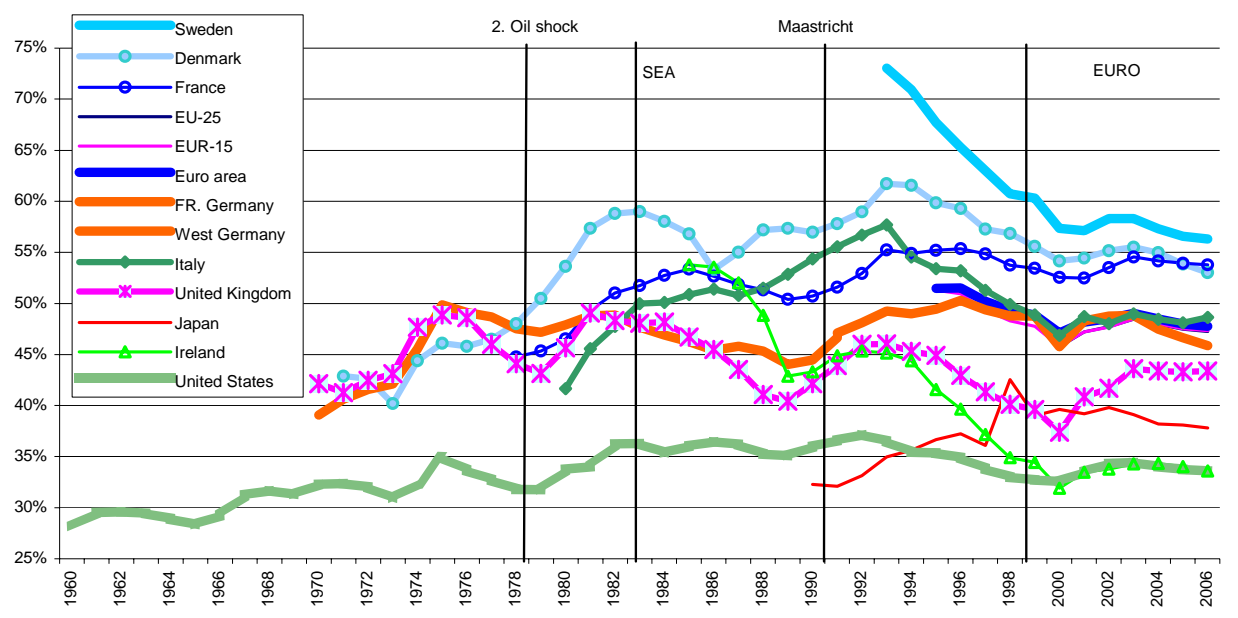

Preferences for the size of the public sector are specific to each nation state. This is also apparent from Figure 2, which shows the distribution of government shares for all 25 EU countries in 2005. The mean expenditure share for the EU-25 is 46.7 percent, with the minimum at 34 and a maximum at 56.6 percent. The standard deviation is 5.4 percent, but the distribution fails the normality test (the $\mathrm{Chi}^{2}$-test gives values of 2.2923 [0.3179 p-value] and the skewness indicator is -0.589). Hence, we conclude that there is not one uniform pattern of government expenditure in the European Union from which individual countries deviate randomly. Instead, each country determines its own allocation of resources for public goods. However, Figure 1 also reveals that, at least since the ERM crisis in 1992/3, the growth of public expenditure has developed more uniformly, lagging behind GDP growth, so that the 
government share has fallen. This may reflect the constraining force of the Maastricht convergence criteria, for the fall in the public spending share does slow down after 1999. ${ }^{3}$

Figure 2. Public expenditure share in the EU, 2005

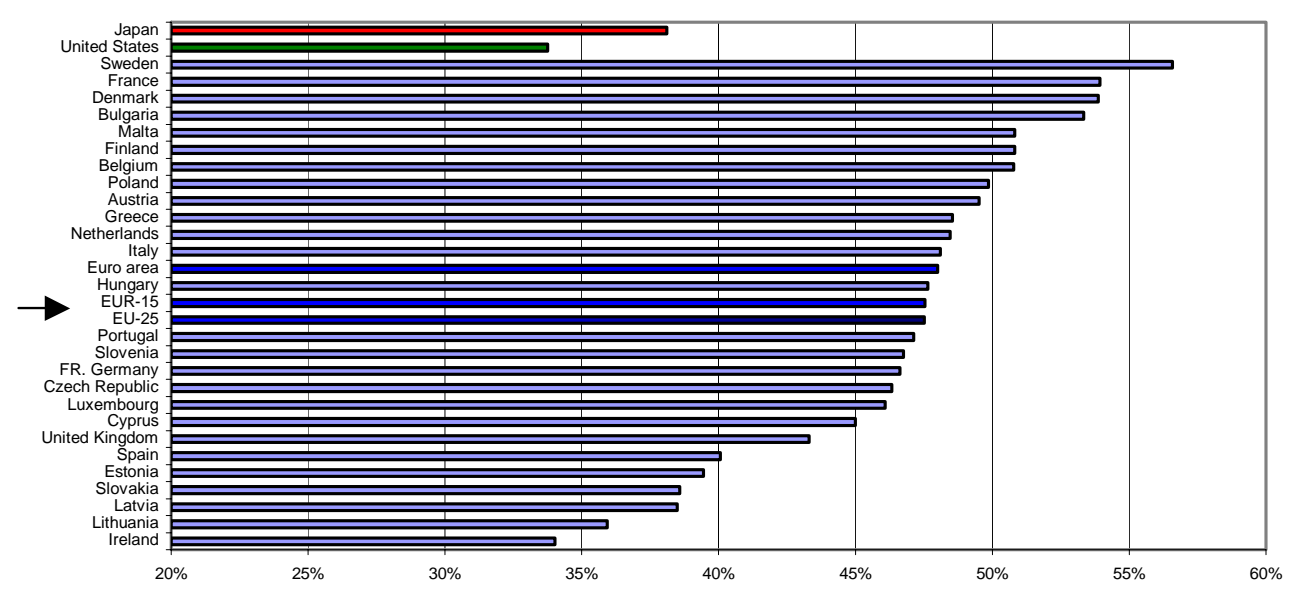

European integration has had far reaching consequences for the allocation of resources in Europe. After the Keynesian era with its strong fiscal activism at the level of the nation state, the Single European Act in 1986 represented the breakthrough of neoclassical supply-side economics, seeking to improve the efficiency, competitiveness and growth of the European economy by improving the allocation of resources across Europe. The "price of Non-Europe”, so convincingly analysed by Cecchini (1988), reflected the opportunity costs of misallocated resources due to obstacles and protection in intra-European trade. The realisation of the single market released significant efficiency gains for the production of private goods, even if the empirical evidence is difficult to measure (Ziltener, 2004). Yet, with the emergence of a fully integrated market, the likelihood of externalities and market failure at the European scale also increased. New forms (or modes) of regulation were therefore required. Quasi by definition, such European regulation could no longer be confined to individual nation states. For example, the single market implied lower prices and mark-ups due to more competition and restructuring of the industrial tissue, with small companies losing out to larger ones with negative consequences for the localisation of employment and positive effects for productivity. Achieving a more efficient allocation of resources also mobilised protectionist resistance. Trans-

\footnotetext{
${ }^{3}$ All data used in charts and table in this paper are taken from the AMECO data base of the European Commission DG ECFIN unless indicated otherwise.
} 
European market building required the delegation of the single market program to the European Commission. Subsequently new policy areas, such as monetary policy and European social policies, were brought into the European domain, some by federal institutions (like the ECB), and others by intergovernmental coordination. But the direct provision of public goods by government remained essentially at the nation state level.

Although the Delors I and II packages introduced interregional re-distribution policies, the share of EU-expenditure has remained extremely limited. It is true, the total EU-budget is larger than the GDP of (mostly new) 10 member states, ${ }^{4}$ but the share in total EU-GDP remains below 1.1 percent. This is in stark contrast with fully developed federal states, where the central government's contribution is significantly higher. For example, central government expenditure varies in Australia, USA, Switzerland and Germany between $8 \%$ and 14\% of GDP, and if social security is included between $18 \%$ and $31 \%$, while state and local government only spend between 10\% and 14\% (Ardy, 2004). Such proportions are considered unacceptable in the European Union.

European integration therefore has had a paradoxical effect: on the one hand, optimising the allocation of resources across Europe required deregulation at home, re-regulation at the European level and the centralisation of monetary policy, while the allocation of resources to public goods remained under the authority of national governments. On the other hand, every euro spent by national governments adds to aggregate demand at the level of the Euro-area. The national allocation of resources therefore causes externalities for all Euro-zone consumers that need to be internalised by aggregate stabilisation policies. The theory of fiscal federalism has always insisted that the allocative function should remain at lower government levels, because their democratic accountability assures that policy decisions would reflect local preferences for public goods. But the stabilisation function can only operate efficiently, if the definition of total expenditure is centralised at the federal level (Musgrave, 1959). Europe's fiscal constitution reveals this dilemma: how could European monetary

\footnotetext{
${ }^{4}$ Malta, Estonia, Latvia, Cyprus, Lithuania, Luxembourg, Slovenia, Slovakia, Hungary, Czech Republic.
} 
union pursue an efficient stabilisation policy, when expenditure at the European level is so low?

\section{Stabilisation Policy}

Stabilisation policy is related to monetary policy and emerged as an unintended consequence of the Single European Act. The attempt to optimise resource allocation inevitably required a single currency as a second step (Padoa-Schioppa, 1987). For if the exchange rate is determined as the relative price of assets in foreign exchange markets, market volatility would continuously distort the optimal allocation of resources. Centralising monetary policy in the ECB was therefore necessary in order to secure the functionality of the single market. This insight became consensual knowledge among policy makers in the Delors Committee, which prepared the Maastricht Conference. During the 1980s, different ideas circulated in Europe. The Bundesbank always insisted that, due to its discretionary nature, monetary policy needed to be centralised in a "federal" authority, while rule based approaches to monetary cooperation in the form of a European Monetary Fund and the development of the Ecu were also under discussion (Heisenberg, 1999, Collignon and Schwarzer, 2002). From a systemic point of view, the Bundesbank was right. An institutional arrangement of "One market, many monies" is normatively inconsistent with a modern market economy, where money serves as the hard budget constraint, against which the scarcity of resources and their most efficient allocation is measured. Money cannot serve as the hard budget constraint, if one market operates with several monetary standards. ${ }^{5}$ The creation of the European Central Bank was therefore the correct answer to the transformation of the European market economy.

However, the creation of a fully integrated financial market also facilitated governments' borrowing. If money is to be the hard budget constraint in the economy and price stability is to be maintained, the central bank has to keep money scarce, or,

\footnotetext{
${ }^{5}$ This is a statement of normative validity, not of empirical truth. No doubt, a large single market can tolerate some small free-riders, who do not share the same currency but benefit from the single market's stability. On the other hand, it was certainly no coincidence that the switch from bimetallic standards to the gold standard in the late $19^{\text {th }}$ century was characterised by rapid economic growth. See Bordo, 1999:159
} 
what amounts to the same, limit the supply of money. On the other hand, the existent of efficient capital markets implied that access for borrowers is free. This implies that funds available in capital markets are a "common resource", and access to them follows the logic of strategic complementarities. Theory would therefore recommend that a federal fiscal authority is needed in order to overcome the potential collective action problems (Inman and Rubinfeld, 1992).

However, before discussing the institutional issues of stabilisation policy, we must ask: How relevant is fiscal policy for achieving fundamental equilibrium? During the anti-Keynesian counter-revolution of the 1970s and 80s, the idea that fiscal policy could make a positive contribution to stabilisation and growth has fallen into disrespect. For example, the Ricardian Equivalence Hypothesis (Barro, 1974) denied the Keynesian assumption that government net expenditure could compensate shortfalls in private sector demand. Budget policies were considered ineffective with respect to "real" economic variables, but they could cause inflation in the long run. However, if consumers do not internalise the future tax implication of current deficits (assuming "future generations will pay for them”), Ricardian Equivalence fails and budget deficits do matter for stabilisation. Thus, the nature of expectation is crucial for explaining the effects of fiscal policy, although fiscal discipline was seen as always necessary to ensure monetary and financial stability. This could be achieved by binding fiscal rules. Institutions for the active pursuit of macroeconomic stability were not deemed necessary. Furthermore, even Keynesians had lost confidence in the efficiency of fiscal policy. The inability to find a satisfactory way of formulating discretionary fiscal policy as an implementable rule and a set of practical institutions to support that rule (especially in a regime of floating exchange rates) had made them sceptical of attempts to use discretionary fiscal policy to stabilize the business cycle (Eichenbaum, 1997:237). The practical debate about stabilisation policy has therefore increasingly centred on monetary policy. ${ }^{6}$ However, fiscal policy has not disappeared from the agenda and in recent years a new consensus has emerged. It favours balanced budget rules, but recognises that the operation of automatic stabilisers (changes in government revenue and expenditure that arise automatically from fluctuations in economic activity) can smooth the business cycle. Discretionary fiscal

\footnotetext{
${ }^{6}$ I will return to this subject below and show that Europe's fiscal arrangements actually impede efficient monetary policy.
} 
demand management is to be avoided, as automatic stabilisers introduce sufficient flexibility into rule-based policies, but it is acceptable for supply-side purposes, such as improving the potential growth rate, covering pension liabilities, creating labour market flexibility, etc. (ECB, 2004). Thus, automatic stabilisers can contribute to the efficiency and stability of macroeconomic policy, while discretionary supply policies should reflect more fundamental collective policy choices.

The debate among economists about the conduct of appropriate macroeconomic policies is, however, usually framed in an institutional context, where the stabilisation effects are derived from centralised budgets. In these cases there is a transparent (although not necessarily optimal) fiscal policy stance and monetary policy can adjust in order to produce stability. Yet, in European monetary union, this argument no longer holds, as Europe's institutional arrangements do not allow the pursuit of an integrated fiscal policy. Hence, macroeconomic stability is not the result of coherent policies, but a random event. There are two institutional approaches to achieve efficient fiscal stabilisation policy: a large federal budget, as in the USA, or strong binding rules as in EMU. In the United States, a significant part of the allocation function is at state level, but the stabilisation function is centralised, as the federal government provides transfer grants, when tax revenue fall short of planned balanced budgets. Earlier EU-documents, like the MacDougall Report (1979) argued for large European budgets in the context of stabilised exchange rates. The Delors Report (1989:94) still gave a prominent role to fiscal policy: "Both for the purpose of internal macroeconomic objectives and in order to be able to participate in the process of international policy coordination, the Community will require a framework for determining a coherent mix of monetary and fiscal policies”. But the accent had shifted from the aggregate to national concerns. Fiscal policy at the European level was now to prevent the "undue appropriation of EMU savings by one country" (Delors Report, 1989, p. 95) and the crowding out of private savings through excessive deficits. A large "federal” budget seemed politically unacceptable (BiniSmaghi, Padoa-Schioppa, and Papadia, 1994). Without sufficient sources of legitimacy, Europe opted for a fiscal policy framework based on rules, rather than on federalist principles. 
Yet, according to the theory of fiscal federalism, there is a dilemma. An efficient European budget would need to be small from the point of view of allocative efficiency, but large for stabilisation purposes. The efficient allocation of resources requires that the optimal level of public goods (i.e. that for which the sum of resident's marginal benefits equals marginal cost) reflects the differences in local preferences and costs; because preference heterogeneity is assumed to increase with the number of citizens, decentralisation is supposed to increase welfare and a big EU budget is undesirable. ${ }^{7}$ Yet, if government expenditure is to make a difference in terms of smoothing aggregate demand and income, it must be substantial. As Lamfalussy put it in the Delors Report (1989, p. 95): “The size of the Community budget would clearly be too small to provide for an adequate masse de manoeuvre for an effective macro-fiscal policy. As a result, in an EMU an appropriate aggregate fiscal policy could not be determined without impinging on the autonomy of national budgetary positions”. Given that most of public spending in the EU is undertaken by member state governments (see Figure 1), the stabilisation function in Euroland must work through national budgets. The aggregate fiscal policy stance in Euroland, which matters for monetary policy, is then simply the bookkeeping result of adding up the different national budget positions.

The solution to the dilemma proposed by the Maastricht treaty was the excessive deficit procedure. Member states were free to define the amount of resources allocated to public goods, as long as they financed them by raising taxes. But excessive demand impulses (and unsustainable debt build-ups) were to be avoided by following the rule of not exceeding public borrowing by more than 3 percent of GDP. Later this simple rule was strengthened by the Stability and Growth Pact (SGP), which stipulated the norm of balanced budgets. However, given the fact that public authorities are usually the single most important debtor in capital markets, regulating public borrowing is important, not only to prevent financial market instability, but

\footnotetext{
${ }^{7}$ As Oates (2004, pp. 26- 7) points out, “decentralised levels of government focus their efforts on providing public goods whose consumption is limited primarily to their own constituencies. In this way, they can adopt outputs of such services to the particular tastes, costs, and other circumstances that characterise their own jurisdictions.” Thus, in this decentralising theory of fiscal federalism, which Europeans call subsidiarity, there is no place for spillover effects of public goods into other constituencies. In Collignon (2003) I have argued that this model is not suitable for policy analysis in the European Union, where spillover effects are widespread. Many collective goods are consumed by all European citizens, although there are no institutions to match policy output with the democratic policy input.
} 
also to maintain favourable conditions for economic growth. This logic provides a justification for the SGP. But it does not provide a solution for the collective action problem, which would require an institution capable of implementing a coherent policy, as already seen by David Hume.

Contrary to what is often claimed in the public debate, the issue is not the role of automatic stabilisers. Indeed, if all countries balanced their cyclically adjusted budgets, so that structural deficits were zero, the likelihood of exceeding the 3-percent margin would be low for all member states (Dalsgaard and de Serres, 2001). The automatic stabilisers could therefore work, as they should. The real issue is that many member states' structural deficits are not balanced. In fact, in most countries structural deficits have deteriorated since EMU started; the aggregate position has moved from 1.6 in 1999 to 2.5 percent of GDP in 2004 (see Figure 3). Six out of 12 countries have cyclically adjusted deficits in excess of 2 percent of GDP, so that it is not surprising that they hit the excessive deficit limits during a period of growth stagnation.

Figure 3. Structural deficits in Euroland

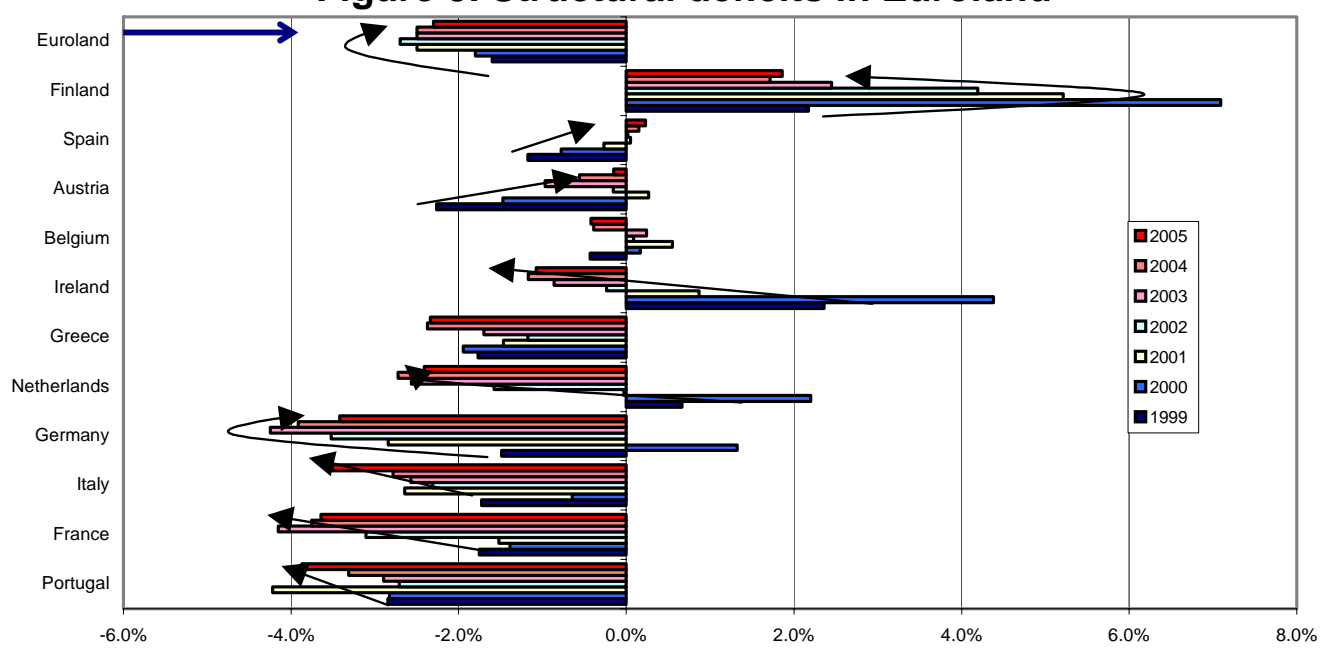

The evolution of structural deficits reflects the unsolved issue of democratic legitimacy for fiscal policy. Without an authority that has been empowered by the European sovereign, i.e. citizens, national governments are the only institution that can claim to represent a democratic mandate. "No taxation without representation” implies here, that only member state governments may decide on budget balances, 
even if this causes significant externalities. Collective action logic pushes to the increase in structural deficits, as the cost of borrowing seems to be lowered by collective restraint, so that each member state is tempted to borrow more. A policy rule agreed by governments does not carry the same weight as the policy mandate received from the ballot boxes (Collignon, 2004a).

\section{Redistribution function}

Legitimacy issues also overshadow the redistribution function of Europe's public finances. It is usually agreed that given the unequal initial distribution of resources, governments may correct market allocations in order to preserve norms of justice and fairness. The degree to which this is done remains open to debate. Technically, it is clear that a just state of distribution has to be derived from a social welfare function and a tax transfer constraint. But in practice "the shape of the social welfare function as an instrument of social policy remains to be determined through the democratic process” (Musgrave, 199:46) and governments intervene as the agent charged by citizens. These interventions must be done by central governments. Tiebout (1956) has argued that, given free movement of factors of production, individuals will select the jurisdiction whose provision of local public goods and tax structures best satisfies their preferences. Lower level governments may therefore create distorted incentives leading to tax evasion as wealthier citizens are moving to low taxing jurisdictions (voting by their feet). ${ }^{8}$ Drawing the conclusion from the theory of fiscal federalism Inman and Rubinfeld (1991:657) recommend “central government intervention”.

Centralising redistribution policiesmay also become necessary to strengthen the general acceptance and democratic legitimacy of European integration, as an un regulated single market may undermine traditional social models in the member states. With mobile households and a common citizenship, the marginal tax costs of income redistribution within each member states increases as each as each euro

\footnotetext{
${ }^{8}$ The most extreme form of imposing externalities on other groups is the so-called systemic or regulatory competition. Assume a large group of citizens vote by their feet for lower taxes by moving into a low-tax jurisdiction. This imposes tax cuts on the high-tax jurisdiction, which is in danger of losing its tax base. As a consequence the voters who would have preferred a larger public sector are forced to put up with a policy choice that does nor correspond to their preferences. But of course the opposite externality accrues for those who do not want to pay high taxes but stay in a high-tax jurisdiction.
} 
transferred by an upper income household to a lower resident is likely to attract new low income residents from neighbouring states. Hence, as high-income factors of production become more mobile, it will prove increasingly difficult for any state jurisdiction to achieve redistribution goals independently of other jurisdictions; attempts to redistribute within a jurisdiction will simply drive out mobile factors (Cullis and Jones, 1998:304). This mechanism seems to have become a major threat to national welfare state models since the arrival of a large number of new member states with low per capita income. It is feared that the freedom of movements for labour may lead to large migration of workers and wage competition or to the reallocation of capital (delocalisations), levelling incomes not only by lifting poorer countries up, but also by bringing income in richer countries down. Thus, decentralised redistribution policies as practiced in the EU today are undermining not only national redistribution systems, but also the acceptability and legitimacy of European integration, as the failed referenda on the Constitutional Treaty in France and the Netherlands have demonstrated.

Furthermore, redistribution at the European level is essentially about redistribution of income between states, rather then between citizens. Common agricultural policy apart, most of the intra-EU transfers are channelled through regional cohesion policies. Structural funds are targeted to regions, where per capita income is less than 75 percent of the average EU per capita income. Cohesion funds were created in 1994 as an instrument for Ireland, Portugal, Spain and Greece to manage the fiscal convergence to the Maastricht criteria. Today they are aimed at financing interregional transport, infrastructure and environmental protection, in countries who's per capita GDP is less than 90\% of the Community average. Effectively these funds work as a subsidy to national budgets. This is why negotiations about the multi-annual financial framework are so acrimonious. National treasuries pay into the common kitty and look at how much they are "getting back". Margaret Thatcher succeeded in obtaining a rebate for Britain's contribution, but taxpayer resentment of being a high net contributor is generally widespread in the EU. It was prevalent in the Dutch referendum and has dominated the German political discourse about Europe for a long time. 
Legitimacy issues are highly sensitive in the domain of redistribution policies, as the trade-off for wealth expropriation by taxes is fairness and justice, a diffusive normative concept rather than a tangible benefit in terms of public goods.

\section{Normative Foundations of Fiscal Policy in Europe}

Legitimacy is a source of power (Collignon, 2003:59-63). Both are necessary prerequisites for efficient fiscal policy, because without the collective acceptance of either the actual choices or the general rules, according to which individuals may be taxed and therefore deprived of their wealth, the optimal allocation of resources to collective preferences is not possible. However, legitimacy draws on normative models of policy justification, which may lead to different institutional arrangements and policy outcomes. Eriksen and Fossum (2004) have crystallised three models of normative justification for the European integration process: The EU as a problemsolving entity, which is legitimised on technocratic grounds, a value-based community, which appeals to communitarianism, and a rights-based political Union, which is close to what I have called a European Republic. Each of these concepts provides different justifications for EU fiscal policy. I will now link the different functions of public finance to these potential sources of legitimacy.

The EU as a problem-solving entity

The first model focuses on efficiency and follows an instrumental and technocratic logic. Legitimacy depends on the ability to solve problems efficiently and on the capacity to deliver public goods that people want. Scharpf (1999) has called this the model of output legitimacy. Tony Blair is probably its most prominent follower. This doctrine focuses on tangible and material (net) benefits derived from EU membership. The European Union is conceived as a functional organisation, not as a community of values or a public venture to manage common concerns. Cooperation, participation and membership are premised on the ongoing calculation of costs and benefits. Thus, intergovernmental relations and strategic interactions between governments in search of maximising advantages for their local and partial constituencies dominate the interpretation of how EU policies should be defined. 
This approach is well suited to the allocative function of fiscal policy. If resources are efficiently allocated, welfare is maximised and the policy must be optimal in terms of delivering the collective goods desired by citizens. Notice also that this interpretation necessarily assumes collective preferences as given, so that decentralised policy making is welfare enhancing if preferences are heterogeneous. In other words, the EU as a problem-solving entity corresponds perfectly to the neoclassical and liberal paradigm of market autonomy and subsidiarity that is underlying the creation of the single market in Europe.

However, this approach leads to serious shortcomings, if the decentralised provision of collective goods causes significant externalities with strategic substitutabilities. First of all, while the welfare enhancing aspect of a problem-solving EU attracts new members, its capacity to deliver the desirable public goods to the Union as a whole decreases and output legitimacy diminishes. As the number of decision makers increases, collective action problems become more salient, at least in the domain of exclusive collective goods. As a consequence, output legitimacy in a problem solving European Union tends to eliminate itself. Because efficient policy output is the only source of legitimacy in this model, there is no other criterion, whereby the inflation of potential decision makers could be contained. The EU will keep enlarging until the overall net benefits turn into a loss and there is a growing risk that the Union will break up - first at the margin and then in a sudden collapse. The logic of this development can be explained in simple neoclassical terms (North, 1981): while the net benefit for new member states from joining the EU is positive, the collective benefit for old members from staying in the Union is diminishing due to increased transaction costs among many members. Hence, these externalities drive a wedge between the "individual” marginal cost of membership and the marginal "social” costs of accepting new member states, and this wedge undermines output legitimacy. ${ }^{9}$ The answer would be to define property rights for these externalities, but this would imply a different cognitive framework ${ }^{10}$ from that of the problem-solving EU. The model would have to explicitly incorporate collective preferences across the EU, something that the intergovernmental structure of the model does not permit.

\footnotetext{
${ }^{9}$ For a formal model of this logic, see Collignon, 2003, Annex 2.

${ }^{10}$ North, 1981, discusses such cognitive frameworks under the notion of ideologies.
} 
Secondly, the shortcomings of the problem-solving approach are particularly severe with respect to stabilisation policy. The new orthodoxy of "balanced budgets over the medium term” and automatic stabilisers as cyclical adjustment mechanism would certainly be welfare maximising, if all European citizens shared the same collective preferences and agreed that borrowing for public investment and higher consumption by the present generation was undesirable. However, there is no systematic reason, why this should be the case. To the contrary. Time preferences, like all collective preferences, emerge from democratic debates and deliberations. As new evidence is appearing and taken into account, debates change and preferences shift. Usually public policy debates are centred on electoral contests for different government policies and leadership. Under the subsidiarity principle, the constituencies within which these debates take place are locally defined and do not cover all of the European Union's citizens. Hence, time preferences for allocating resources across time may also change and, therefore, structural deficits, too. Witness the example to France' deteriorating structural budget deficit after the re-election of President Chirac in 2002 (see Figure 3) or the switch from budget surpluses to deficits in the USA after President Clinton was replaced by Bush jr. Yet, because policy deliberation in Europe is contained in national constituencies, preferences for structural deficits are not shared across Euroland and the norm of balanced budgets stipulated by the Stability and Growth Pact will not necessarily correspond to the political preferences in all individual member states.

An effective stabilisation policy implies that there is only one aggregate fiscal policy stance compatible with a given monetary policy. Who is responsible for determining this equilibrium? There are two possible answers: first, if fiscal policy remains decentralised and determined at the national level, the aggregate European position is the sum of random national positions. In pursuit of macroeconomic equilibrium in the Euro-area, the central bank will then only be able to adjust interest rates passively to a level that is compatible with the expected aggregate budget outcome. In this case, monetary policy behaves as a Stackelberg follower to a diffuse and random fiscal policy process of 12 governments. But the larger the random error in the aggregate position, the higher is the uncertainty for the ECB about the appropriate interest rate. Thus, monetary policy is likely to be slow in reacting to shocks and inefficient as a 
stabilisation tool. Euroland's lacklustre economic performance must therefore be blamed on the institutional set-up of fiscal policy, rather than on the specific policies chosen of the ECB. ${ }^{11}$ Furthermore, it is impossible to conduct a proper EU stabilisation policy from the fiscal side, given that a policy is defined as a sequence of deliberate decisions to maximise common objectives such as welfare, while thjere is no single elected agent responsible.

Secondly, an alternative to the decentralised model is to impose a general rule that will constrain individual member state budget deficits and therefore define implicitly an aggregate fiscal policy stance. The SGP is such a rule, because if all member states keep their structural budget in balance, the aggregate structural deficit is zero. But given that this rule does not necessarily reflect the preferences of all citizens as policy debates are confined to national constituencies, it is likely to produce suboptimal outcomes. The resulting welfare losses reduce the output legitimacy of the SGP. The lesson is clear: the institutional reproduction of preference heterogeneity by Europe's splintered polity prevents sustainable efficient and democratically legitimate fiscal policies.

Deficiencies of the problem-solving approach to the EU also dominate redistribution policies. The legitimising arguments for such technocratic redistribution policies are usually framed in terms of side-payments in intergovernmental negotiations or for compensating losers of Pareto-optimality when decision-making procedures are close to unanimity, but rarely do they refer to fairness and justice. For example, Germany's net transfers to the EU-budget have long been considered a price well worth paying for the benefits obtained from participating in the single market. More generally, the funds flowing from richer to poorer countries were seen as a premium for peace and stability (Sinn, 1994). But again, if this is the only basis for justification, European cohesion policy stands on fragile feet. As the sense of fairness and justice is not generally shared across political constituencies, Thatcherite "rebate policies" will undermine the EU's capacity to "solve problems" of European public goods. Shocks to domestic preferences, such as German budget commitments resulting from the absorption of the East-German economy into the united Germany, may quickly

\footnotetext{
${ }^{11}$ And of course even less blame is to be put on central bank independence, as some politicians seem to believe.
} 
change the relative position of costs and benefits. The legitimacy of EU redistribution policies and the sustainability of EU-cohesion remain therefore based on weak compromise, rather than on collectively shared consensus.

We may conclude that the problem-solving model of the EU may be suitable to legitimise early stages of integration, when shared public goods are still few in numbers and externalities are rare and limited. Thus, output legitimacy is well suited to international relations (Moravcsik, A. 2004). Yet, as integration deepens, spillovers from national governmental decisions to citizens living in other member states of the Union become increasingly less capable of producing output legitimacy. Preserving the process of European integration will then require additional sources of legitimacy.

\section{Communitarian sources of legitimacy}

An obvious additional source of legitimacy is a set of shared values. This cognitive framework is derived from common cultural background knowledge, which facilitates a coherent re-interpretation of individual preferences and their mapping into the collective domain. ${ }^{12}$ As Eriksen and Fossum (2004:442) put it: "to be legitimate a common identity is needed to secure trust. (...) Every political order presupposes some kind of cultural substrate to foster allegiance and respect for laws”. In this communitarian perspective "people" are turned into "compatriots" (brothers and sisters) with special bonds of solidarity. Legitimacy stems from primordial sources of belonging that constitute the identity of the group and provide the cultural substrate for collective decision-making (Miller, 1995, quoted by Eriksen and Fossum, 2004). Notice that contrary to the technocratic problem-solving model, communitarianism is incompatible with methodological individualism; individuals are not defined by their desires, preferences and interests, but by the common property that codifies their common culture. However, the bonds of solidarity within a community are dependant on "weak" or "strong" ties between individuals, to use the classical distinction by

\footnotetext{
${ }^{12}$ In my (2003) stochastic consensus model, I have described this as step II of the collective preference formation process.
} 
Granovetter (1973). Strong ties contribute to the feeling of common identity. ${ }^{13}$ In Europe, the communitarian conception of policy making has two dimensions: one is the "Euro-nationalist" (Menéndez, 2005) or "European federalist" orientation, as it is more frequently called. ${ }^{14}$ The other variant is the Euro-sceptic attachment to the national community and the traditional nation state.

A communitarian conceptualisation of the European Union emphasises the set of ethical values, shared by all European citizens (Menéndez, 2005). Usually these are positive norms to which general agreement is easily obtained. The Constitutional Treaty, for example, emphasised the role of common values such as human dignity, freedom, democracy, equality, human rights, tolerance, justice and solidarity in article I-2. But Helmut Schmidt (2000:209) has pointed out that "common errors and sins" are also part of the European cultural inheritance: crusades, anti-Semitism, the inquisition, burning of witches, torture, and wars of conquest, plunder and destruction. All these positive and negative historic experiences have created a cognitive framework, which has given rise to a we-feeling among Europeans, although its intensity may not be shared equally among all citizens and competes with national identities. The sense of European citizenship is regularly measured by Eurobarometer. Figure 4 gives an indication of the strength of Euro-nationalism relative to traditional nation state identification. The strengths of identification with the cultural substrate of the nation state is measured by the number of citizens that see themselves either exclusively as citizens of their own country, or first as citizens of their country and then as Europeans. I have regrouped under Euro-nationalism all other responses that do not give priority to their national state identity. 85 percent of all European citizens show the strongest identification with their nation state, 37 percent even exclusively. Only 15 percent consider European citizenship to be equal (7\%) or more important (4\%) than their national identity. 3 percent identify themselves exclusively with being European (no reply 1 percent). With the exception of Poland and Slovakia identification with Europe is highest in old member states, although it is particularly low in Scandinavia, the UK and the Netherlands.

\footnotetext{
${ }^{13}$ The strength of ties turns out to be crucial for the speed of convergence to consensus in a society, which starts out with heterogeneous preferences but remains open to learning and interactive deliberation. See Collignon and Al-Sadoon, forthcoming.

${ }^{14}$ I have taken issue with the communitarian concept of federalism in Europe, as it is historically linked to the anti-cosmopolitan view of a "closed society" and promotes the hypertrophy if "subsidiarity". See Collignon, 2003, chapter 4.
} 


\section{Figure 4. Citizenship feeling in the EU}

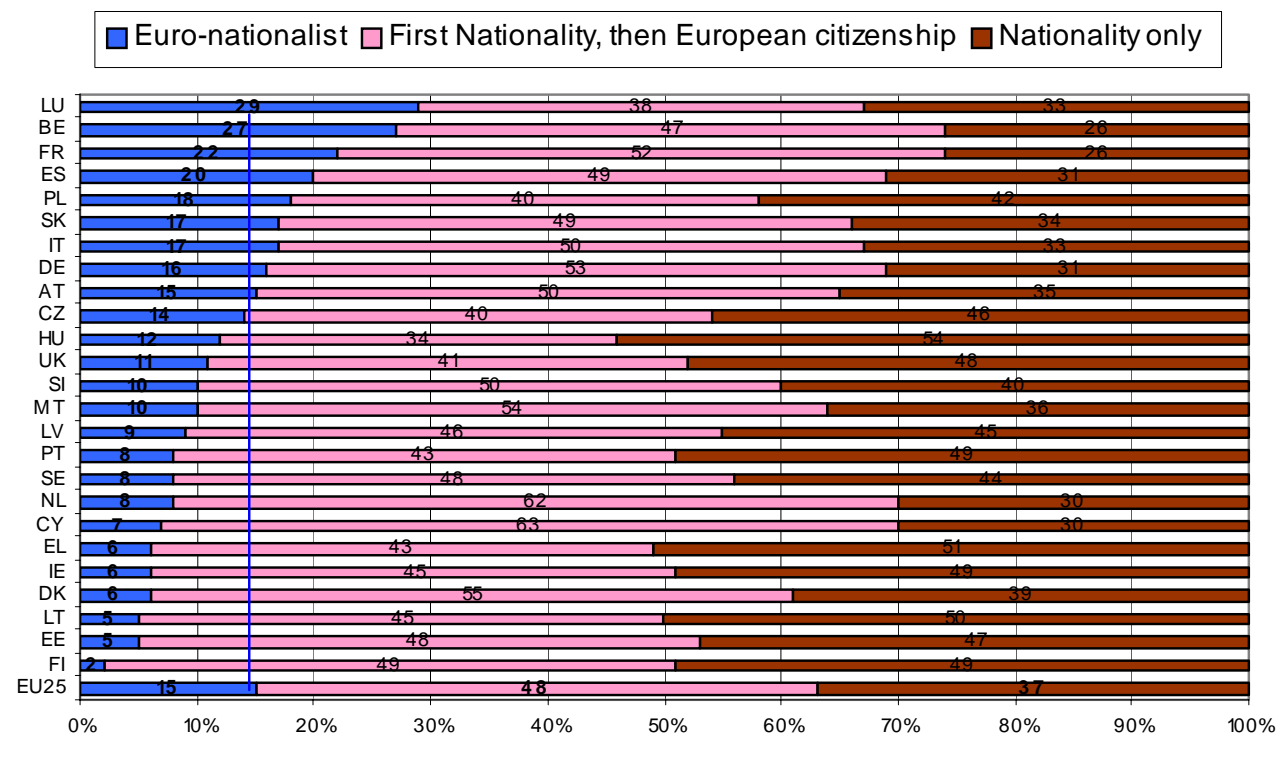

Source: Eurobarometer 62

What are the implications of communitarianism for fiscal policy? For Euronationalists, policy centralisation at the European level is required in order to defend common European values. For fiscal policy this implies a large US-type federal budget, as advocated in the MacDougall Report (1979), or at least an expansion of the EU budget to provide common goods, such as European security and defence policies, protection against terrorism or more spending on research and development or education (knowledge society). It seems relatively easy to find agreement for public spending priorities in these policy areas and the allocation of resources to these ends would be welfare optimising. With respect to stabilisation policy, Euro-nationalists generally focus more on external equilibrium and the international dimension of the euro, than on matters of internal efficiency. This results from the fact that communitarians consider the community as a "whole", rather than the individual parts and their interactions. Thus, speaking with one voice and acting as one actor in international institutions such as IMF, World Bank, G7 etc. is one of their major concerns. Given that there is no large federal budget in Europe, Euro-nationalist seek at least to improve the coordination of fiscal policies in the context of the multi-level governance in Euro-group. The fact that this forum for intergovernmental policy coordination has not direct legitimizing input from European citizens does not seem to weaken its legitimacy over all, given that the desirability of policy coordination is 
value-based. Similarly, European-wide re-distribution policies seem legitimate from this point of view, as solidarity within the EU, and more specifically between rich and poor countries, is based on moral or ethical imperatives derived from the shared common knowledge of what is good and proper.

However, the communitarian conception of the EU as a provider of legitimacy is handicapped by some serious drawbacks, which are reflected in the Euro-sceptical position. By deriving legitimacy from a "primordial belonging”, communitarians necessarily focus on what Habermas (1988) has called the "living world" (Lebenswelt) that "is always already there". In other words, the communitarian view draws legitimacy from conventions and norms that are consensual common knowledge within given communities. Notice, that collective preferences are again exogenously given in this model - as they were in the problem-solving interpretation. But in the European context, the "community", within which conventions are shared, is predominantly the nation. As Habermas has shown, the sense of We-feeling in nation states, particularly in the form of "constitutional patriotism", is to a large degree a function of the mechanisms of political deliberation and the institutions of democracy. Thus, given that the European Union has been founded by nation states with (mostly) long histories, a value-based Europe is necessarily characterised by value pluralism and by conflicting views of the common good within and among groups, local communities and cultures (Eriksen and Fossum, 2004:443). The historically and institutionally determined preference heterogeneity is significantly more persistent between nations than within nation states, because the EU does not have the same institutional depth for political deliberation that characterizes democracy in nation states.

As a consequence, communitarian models of legitimacy privilege nationalist policymaking solutions over European ones. Democracy is thought to be dependent on a culturally homogenous pre-existing "demos" and not on procedures to come to acceptable choices on public goods. This fact poses serious problems to the conduct of European fiscal policies. It calls for the allocation of resources to public goods to be decentralised, and subsidiarity becomes the dominant principle. Europe does not seem to have a right to get involved with the wishes and preferences of local citizens. The fact that these local decisions may have spillover effects on other constituencies 
and causes collective action problems is cognitively blended out, because the coherence of the value-based approach to policy making requires ignoring (“tolerating”) the validity of other value systems. Thus, if “our” country likes low taxes and yours likes high taxes, so be it. But the systemic inconsistency of the two attitudes coexisting within the same economy, so clearly described by Tiebout (1956), does not legitimise more centralised European policies.

From a communitarian point of view, decentralisation appears welfare enhancing, but from a problem-solving perspective it is not efficient, because subsidiarity increases collective action problems. This dilemma is even magnified with respect to stabilisation policy. As government borrowing necessarily affects conditions in the capital market and the equilibrium position of the policy mix between the unified monetary policy and the aggregate fiscal stance, externalities in the form of interest and exchange rate levels or inflation are instantaneous and omnipresent. It is therefore only logical, if Euro-sceptics refuse joining European monetary union, as the primate of national policy preferences is incompatible with macroeconomic policy stabilisation at the European level. But by opting out from EMU, Eurosceptics also sacrifice the efficiency gains obtained from a single currency in a single market. With respect to redistribution policy, the Euro-sceptical communitarian approach emphasises lack of a European demos, which is in fact only the mirror image of nationalistic communitarianism. Thus, eurosceptic communitarians claim that there does not exist a sufficient degree of solidarity that would legitimise European redistributive policies.

As we have seen the main answer given by communitarians to the problem of preference heterogeneity is the principle of subsidiarity, but this reduces output efficiency. Thus, there is a trade-off between efficiency and legitimacy in Europe. Yet, contrary to Alesina and Waczirac (1999), I have argued (Collignon, 2003) that the trade-of curve is not stable, but can be shifted by unifying the polity and adjusting its range of competences to the dimension of policy externalities. In other words, when citizens are entitled to choose a European government to administer the public goods that affect all of them (and only those), then they will have to deliberate collectively about those policies and that opens the possibility that they go beyond the established conventions of their living world. Thus, political democracy at the 
European level would contribute to forming a trans-European policy consensus that will gradually become the "cultural substrate" for European decision-making. This idea opens the way to the third model of normative justification for the European integration process.

\section{The European Republic approach}

The technocratic legitimacy of a problem-solving European Union and the communitarian legitimacy of a value-based Europe both implicitly assume collective preferences as exogenously given. Legitimacy is then generated by adapting policies to these preferences, either by maximising efficiency or by minimising centralised decision-making. Both approaches have their limits, as we have seen. We will now look at the third model of justifying EU policymaking and take a transformative view of human beings, where preferences are changed and altered as a consequence of communication and deliberation (Elster, 1998; Dryzek, 2000; Shapiro, 2003). Eriksen and Fossum (2004) have related this deliberative strategy to the rights-based procedural notion of legitimacy. It is premised on the need for continuing the process of institution building at the political level. Transcending the traditional holism of communitarian preference homogeneity, they first recognise that modern constitutions are tied to respect for the integrity and dignity of individuals. ${ }^{15}$ Preference heterogeneity is therefore all-pervasive and disagreements "should be settled by arguments and be reflected in working principle of the polity” (p.443). The contractual principles of modern societies provide the normative foundations for economic and political freedom and equality (Collignon, 2005) and entail rights for protecting the integrity of the individual (private freedom) and for enabling individuals' participation in the public opinion formation and decision making process (public freedom). The conjunction of these private and public freedoms allows democracy to function as a process of deliberation. Democracy as a deliberative procedure for reaching acceptable collective decisions is therefore a source of legitimacy. With respect to Europe, I have called this rights-based institutional

\footnotetext{
${ }^{15}$ Notice the dramatic shift from communitarianism, which protects the integrity of nation states and treats individuals as an abstract cultural code.
} 
arrangement a European Republic to distinguish it from the communitarian federalist model (see Collignon 2004, chapter 4).

However, modelling the process of deliberation has been a challenge. For many writers who pledge allegiance to deliberative democracy, deliberation seems only to work in relatively homogenous groups, who share many values and beliefs, while pluralism would undermine the possibility of agreement and consensus. The size and complexity of modern society seems to make most accounts of deliberation "unrealistic, if not quaint” (Bohman, 1994:2-3). This criticism goes back to Habermas' (1988) “ideal speech situation”, which describes a normative set of conditions for individuals agreeing with each other. However, I believe that ideal speech situations are not a necessary, although sufficient, condition for deliberation. Based on previous work by deGroot (1974) and Lehrer and Wagner (1981), the theory of stochastic consensus has established that there are two conditions required for consensus to emerge after many rounds of deliberation: mutual respect and connectedness. $^{16}$ Given these minimal conditions, it can be shown that communication in society will transform individuals' values and preferences and make them converge to a consensus that is generally accepted and shared by all. Now, it is easily perceived that these weak conditions are fulfilled in most modern societies and specifically in the European Union. Deliberation and preference convergence is therefore not dependent on the existence of an idealised "public sphere" or a preestablished "We-feeling”. All that is needed is that individuals talk and listen to each other and are connected to each other through institutions that structure the exchange of information.

However, even if these conditions allow "ultimately" reaching consensus (after infinite steps of deliberation to be precise), dissent and disagreement are quasipermanent features of this consensus model, as individuals are on the way to, but have not yet accomplished, agreement. I have called “dissent” the variance of individual views from the "ultimate" consensual view. The structure of communication and the degree of trust between individuals will determine the degree of noise and dissent and

\footnotetext{
${ }^{16}$ Mutual respect does not imply equal respect, but simply that there is a chain of respect between individuals that permits information and arguments to be exchanged and accepted to varying degrees among all individuals. See Collignon, 2003; Collignon and Al-Sadoon, forthcoming.
} 
the time it takes until agreement is reached. This means that the procedural arrangements in EU policy making determine not only the ranking of collective preferences, but also the persistence of preference heterogeneity. Justifying EU policy making from the deliberative democracy view is therefore always compatible with the technocratic approach of a problem solving EU. But with respect to the communitarian approach it is only compatible with the Euro-federalist, not with the Euro-sceptical view. The reason is that procedures of a proper European democracy would intensify policy debates across the entire European polity and thereby increase the connectedness of individual citizens and raise the level of cross-border trust. ${ }^{17}$ This will accelerate the emergence of pan-European policy consensus and reduce preference heterogeneity in the Union, at the price of altering the local living worlds that have "always already been there”. Erikson and Fossum are therefore right, when they write (2004:448): "the demos is to be shaped by political means; hence there can be no European demos without a European democracy”.

What does creating a European Republic imply for the legitimacy of fiscal policy? By European Republic I mean simply a political Union with full democratic legitimacy. Thus, it transcends a political Union between governments, where legitimacy is a derivative, such as the EU under the Treaty of Nice or the European economic government suggested at one stage by French authorities. Instead, a European government is in charge of articulating preferences and executing policy choices with respect to European collective goods (and only those), i.e. with respect to policies, which affect all citizens living in the Union. By being politically accountable and having to verify its legitimacy through regular EU-wide elections, e.g. for the European Parliament, political deliberation finds the focus, which is necessary for the rapid emergence of a European policy consensus.

For the allocative function of public finance this implies that European-wide deliberation on the allocation of resources to European objectives will be backed by democratic consensus. This is important for the potential size of the EU budget as well as for the prioritisation of its content: whether money is spent, say, on the

\footnotetext{
${ }^{17} \mathrm{I}$ have modelled the impact by institutional arrangement of connectedness on European policy consensus in Collignon 2003 and the role of trans-border generation of trust in Collignon and Schwarzer, 2002.
} 
common agricultural policy or research and development is then a matter of policy preferences debated by citizens, rather than the compromises and side-payments between governmental administrations. From this point of view, deliberative democracy is welfare enhancing, because it simultaneously reduces preference heterogeneity and legitimised the internalisation of externalities.

A similar argument can be made for re-distributive policies, which according to the literature of fiscal federalism should be centralised at the European level. The structures of democratic policy debate in the EU would contribute to the transformation of citizens' identification with their home country and European citizenship. Thus, democracy is likely to increase the sense of solidarity across Europe, because weak ties between nations are becoming stronger and strong ties within nations are getting weaker. As a consequence it should be possible to break the traditionalist communitarian feeling of "belonging” and instead replace it with a modern sense of solidarity between individuals.

With respect to stabilisation policy, the European Republic would allow an elegant solution to the dilemma that the allocation of resources should be decentralised, while defining an aggregate fiscal stance is required as a counterpart to monetary policy. We have seen that an active fiscal policy approach should entail the possibility of defining long tem (equilibrium) positions of (structural) fiscal deficits that reflect collective time preferences. With today's political institutions this is not possible; but under the European Republic approach the European government would be charged to define the aggregate stance. This policy would reflect deliberations between European citizens, because otherwise the European government may not be re-elected. Technically this aggregate budget position would have to be formulated as a European law, e.g. as a modified form of the Broad Economic Policy Guidelines ${ }^{18}$ or what Amato (2002) has called in reference to the Italian budget procedure a "DPEF europeo”. Once this budget stance has been approved by the European Parliament and the Council, each member state obtains tradable deficit permits, which reflect each

\footnotetext{
${ }^{18}$ Modified, because accountability to citizens implies that it is the European Parliament and not exclusively the Council who should debate and pass this law.
} 
government's entitlement to borrow in the capital market (Casella, 2001). ${ }^{19}$ Without these permits, access to the market is barred. If one government or jurisdiction wishes to borrow more than its assigned quota, it would have to buy deficit permits from other governments who do not wish to use up their quota. This procedure would guarantee that national borrowing remains consistent with the aggregate fiscal stance, which is the relevant reference for the central bank's setting of interest rates. The advantage over the Stability and Growth Pact is that the aggregate stance is more easily foreseeable for all economic agents. The uncertainty that weighs heavily on the ECB today would be lifted, thereby allowing a more active and efficient monetary policy. The legitimacy of stabilisation policy in generals and the ECB in particular would be increased.

\section{Conclusion}

The way different policies are justified to obtain agreement affects policy outcomes. This is the basic message of this paper. But legitimacy is also structured by institutions, and different sources of legitimacy privilege different institutional arrangements. The technocratic interpretation of the European Union as a problemsolving organisation may have been appropriate in the early years of integration, but its previous success is now threatening its demise, as the cost of collective action problems are wiping out the efficiency gains of an efficient single market. The communitarian justification of integration on the basis of shared European values can certainly contribute to increased legitimacy of the Union, but by focusing on communitarian values Europe is more likely to emphasise what divides it than what unites it. In addition, the communitarian subsidiarity principle further reduces the efficiency of Europe's technocratic governance and therefore risks reducing the Union's overall legitimacy. Methodologically, these two sources of legitimacy assume political preferences as given; therefore they cannot explain which institutions are required to lift the collective level of acceptance of European policies. A deliberative approach to legitimacy allows going beyond these limitations and to generate additional legitimacy by creating a political Union with full democratic procedures; I have called such Union the European Republic.

\footnotetext{
${ }^{19}$ Member states may devolve these deficit permits to local authorities and thereby reinforce fiscal discipline at lower government levels.
} 
Fiscal policy is at the core of political legitimacy. Exclusive reliance on either the technocratic or the communitarian models of legitimacy prevents designing a coherent fiscal policy, which would be efficient in the welfare augmenting sense. By making the next step and submitting some functions of fiscal policy, especially stabilisation policy in the Euro-area, to democratic legitimacy at the European level, Europe would not only become more attractive to its citizens, but its economic performance would also be improved.

oOo

\section{Bibliography}

- Alesina, A. and Wacziarg, R. 1999: Is Europe Going Too Far? National Bureau of Economic Research. C.A. Mass. Working paper No. 6883

- Altomonte, C. and M. Nava, 2005. Economics and Policies in the Enlarged EU. Forthcoming

- Amato, G. 2002. Verso un DPEF Europeo ; NENS No.4 (Nuova Economia Nuova Società), luglio, p.15-19.

- Ardy, B. 2004. The Development of EU Budgetary Measures and the Rise of Structural Funding. In: Baimbridge, M. and P. Whyman (eds.), Fiscal Federalism and European Economic Integration, Routledge, London, UK and New York, USA.

- Barro, R. 1974. Are Government Bonds Net Wealth?, in: Journal of Political Economy, 82: 1095- 117.

- Bini-Smaghi, L., T. Padoa-Schioppa and F. Papadia. 1994. The Transition to EMU in the Maastricht Treaty; Essays in International Finance, No. 194, November, Princeton University, New Jersey.

- Bohman, J. 1996. Public deliberation. Pluralism, Complexity and Democracy. MIT Press, Cambridge Mass.

- Bordo, M. D. 1999. The Gold Standard and Related Regimes: Collected Essays. Cambridge University Press

- Buchanan, J. The Limits of Liberty. Between Anarchy and Leviathan. Chicago; University of Chicago Press

- Casella, A. 2001. Trade-able Deficit Permits: in: Brumila, A., Buti, M and Franco, D. (eds.). The Stability and Growth Pact, The Architecture of Fiscal Policy in EMU. London: Palgrave.

- Cecchini, P. 1988 The European Challenge 1992: The Benefits of a Single Market, Wildwood House, Aldershot.

- Collignon and Schwarzer, 2002 Private Sector Involvement in the Euro. The Power of Ideas, Routledge, London

- Collignon, S. 2004. France and Germany: Learning to live in Euroland? To be published by Centre Saint-Gobain pour la Recherche en Economie, Paris. Download from www.stefancollignon.de

- Collignon, S. 2004a. Is Europe Going Far Enough? Reflections on the EU's Economic Governance. Journal of European Public Policy, Vol. 11, no 5 
- Collignon, S. 2004b. Fiscal policy and Democracy; paper presented at Monetary Workshop, Österreichische Nationalbank, Vienna, 2004 ; published as ÖNB Discussion paper No. 4, November 2004

- Collignon, S. 2005. Globalisierung, Regionalismus und die politische Ökonomie von Ideologien. In: B. Fritz und K. Hujo, 2005. Ökonomie unter den Bedingungen Lateinamerikas; Vervuert Verlagsgesellschaft

- Collignon, S. and M. Al-Sadoon, forthcoming. A General Theory of Stochastic Consensus. London, manuscript

- Cooper and John, 1988. Coordinating Coordination failures in Keynesian models. Quarterly Journal of Economics, 103: 441-463

- Cullis, J. and Ph. Jones. 1998. Public Finance and Public Choice ( $2^{\text {nd }}$ edition). Oxford. Oxford University Press

- Dalsgaard, T, and A. de Serres, 2001. Estimating Prudent Budgetary Margins. in: Brumila, A., Buti, M and Franco, D. (eds.). The Stability and Growth Pact, The Architecture of Fiscal Policy in EMU. London: Palgrave.

- DeGroot, M. H. 1974. "Reaching a Consensus" in: Journal of the American Statistical Association, Vol.69, Issue 345 (March), pp. 118-121

- Delors Report. 1989. Committee for the Study of Economic and Monetary Union,. Report on Economic and Monetary Union in the European Community, Office for Official Publications of the European Communities, Luxembourg

- Dryzek, J.S. 2000. Deliberative Democracy and beyond. Liberals, Critics, Contestations; Oxford, Oxford University Press

- Eichenbaum, M. 1997. Some Toughts on Practical Stabilization Policy. American Economic Review, Vol 87, 2: 236-239

- Elster, J. (ed) 1998. Deliberative Democracy; Cambridge , Cambridge University Press

- Eriksen, E.O. and J. E. Fossum, 2004. Europe in Search of Legitimacy: Strategies of Legitimation Assessed. International Political Science Review, 25.4: 435-459

- Eurobarometer 62, 2004. Bruxelles, download : http://europa.eu.int/comm/public_opinion/index_en.htm

- Granovetter, M. S. 1973. The Strength of Weak Ties; American Journal of Sociology, 78,6: 1360-1380

- Habermas, J. 1988. Theorie des kommunikativen Handelns (Vol I and II). Frankfurt a.M., Suhrkamp Verlag

- Heisenberg, D. 1999. The Mark of the Bundesbank. Germany's Role in European Monetary Cooperation. London: Lynne Rienner Publisher

- Hume, D. A. 1978. Treatise of Human Nature (ed. By L.A. Selby-Bigge and P.H. Nidditch) Oxford University Press

- Inman R. and D. Rubinfeld. 1992 Fiscal Federalism in Europe. Lessons from the United States Experience. European Economic Review 36: 654-660.

- Lehrer, K. and Wagner, C. 1981. Rational Consensus in Science and Society; D. Reidel Publishing Company, Dordrecht, Holland.

- MacDougall Report. 1977. EC Commission, Report on the Study Group of Public Finance in European Integration. Office for the Official Publication of the European Communities; Luxemburg.

- Menéndez, A. J. 2005 (forthcoming). The purse of the polity. mimeo

- Miller, D. 1995. On Nationality. Oxford, Oxford University Press

- Moravcsik, A. 2004. Is there a 'Democratic Deficit' in World Politics? A Framework for Analysis. Government and Opposition, 39(2):336-363 
- Musgrave, R. 1999. The Nature of the Fiscal State: the Roots of My Thinking. In; J. M. Buchanan and R. A. Musgrave, 1999. Public Finance and Public Choice. Two contrasting visions of the State, Cambridge, Mass. MIT Press

- Musgrave, R.M. 1959. The Theory of Public Finance, McGrawHill, New York, USA.

- North, D. 1981. Structure and Change in Economic History. New York, W.W. Norton and Co.

- Oates, W.E. 2004. An Essay on Fiscal Federalism, in: Baimbridge, M. and P. Whyman (eds.), Fiscal Federalism and European Economic Integration, Routledge, London, UK and New York, USA.

- Oates. W. 1972. Fiscal Federalism. New York/Chicago, Harcourt Brace Jovanovich Inc.

- Padoa-Schioppa, T. 1987. Efficiency, Stability and Equity: A Strategy for the Evolution of the Economic System of the European Community. Oxford: Oxford University Press

- Scharpf, F.W. 1999. Governing in Europe: Effective or Democratic? Oxford; Oxford University Press

- Schmidt, H. 2000. Die Selbstbehauptung Europas. Perspectiven für das 21. Jahrhundert. Stuttgart München, DVA

- Shapiro, I. 2003. The State of Democratic Theory. Princeton University Press, Princeton and Oxford

- Sinn, H. W. 1994. How much Europe? Subsidiarity, Centralisation and Fiscal Competition; Scottish Journal of Political Economy, 41,1:85-107

- Smith, A. 1976. An Inquiry into the Nature and Causes of the Wealth of Nations. Oxford University Press/ Liberty Press, Indianapolis

- Tiebout. C.M. 1956. A Pure Theory of Local Expenditure. Journal of Political Economy, 64, 5: 416-24

- Wicksell, K. 1896. Finanztheoretische Untersuchungen. Jena: Gustav Fischer

- Ziltener, P. 2004. The Economic Effects of the European Single Market Project: Projections, Simulations - and the Reality. Review of International Political Economy 11:5 December 2004: 953-979 